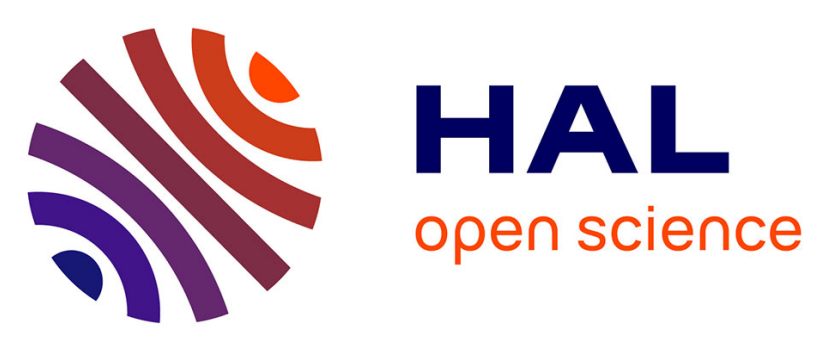

\title{
Developing economies in the current climate regime: new prospects for resilience and sustainability? The case of CDM projects in Asia
}

Pauline Lacour, Jean-Christophe Simon

\section{- To cite this version:}

Pauline Lacour, Jean-Christophe Simon. Developing economies in the current climate regime: new prospects for resilience and sustainability? The case of CDM projects in Asia. 13th EADI general conference 2011 "Rethinking development in an age of scarcity and uncertainty: new values, voices and alliances for increased resilience", University of York, Sep 2011, York, United Kingdom. halshs00676809

\section{HAL Id: halshs-00676809 \\ https://shs.hal.science/halshs-00676809}

Submitted on 6 Mar 2012

HAL is a multi-disciplinary open access archive for the deposit and dissemination of scientific research documents, whether they are published or not. The documents may come from teaching and research institutions in France or abroad, or from public or private research centers.
L'archive ouverte pluridisciplinaire HAL, est destinée au dépôt et à la diffusion de documents scientifiques de niveau recherche, publiés ou non, émanant des établissements d'enseignement et de recherche français ou étrangers, des laboratoires publics ou privés. 


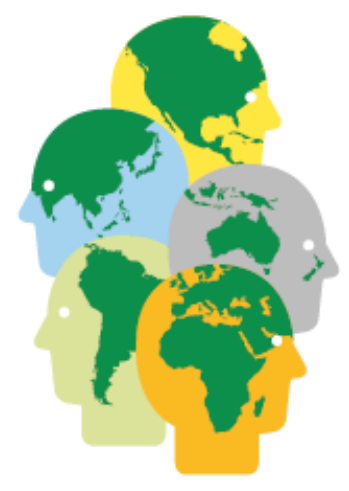

\section{Rethinking Development in an Age of Scarcity and Uncertainty \\ New Values, Voices and Alliances}

for Increased Resilience

19-22 September 2011, University of York

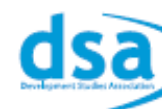

Developing economies in the current climate regime; New prospects for resilience and sustainability? The case of CDM projects in Asia.

\begin{tabular}{|c|c|}
\hline Author: & $\begin{array}{ll}\text { LACOUR Pauline } & \text { Doctoral Fellow } \\
\text { SIMON Jean-Christophe } & \text { Senior research fellow }\end{array}$ \\
\hline Institution: & $\begin{array}{l}\text { CREG research unit, University of Grenoble, France } \\
\text { IRD (UMR 201) \& EDDEN (CNRS) University of Grenoble }\end{array}$ \\
\hline Address: & $\begin{array}{l}\text { BATEG UPMF BP } 47 \\
\text { F - } 38040 \text { GRENOBLE CEDEX }\end{array}$ \\
\hline E-mail: & $\begin{array}{l}\text { jean-christophe.simon@upmf-grenoble.fr } \\
\text { pauline.lacour@upmf-grenoble.fr }\end{array}$ \\
\hline Telephone: & $33-476825423$ \\
\hline
\end{tabular}




\title{
$13^{\text {th }}$ EADI General Conference 2011: Rethinking Development in an Age of Scarcity and Uncertainty: New Values, Voices and Alliances for Increased Resilience
}

\author{
LACOUR Pauline Doctoral Fellow at CREG research unit, University of Grenoble \\ SIMON Jean-Christophe Senior Economist at IRD (UMR 201) and senior research fellow \\ at EDDEN research institute (CNRS, University of de Grenoble)
}

Corresponding authors

jean-christophe.simon@upmf-grenoble.fr

pauline.lacour@upmf-grenoble.fr

\section{NOTE: This is a preliminary version - pending some additional data verification and translation/editing.}

Paper title / Abstract

\section{Developing economies in the current climate regime; New prospects for resilience and sustainability? The case of CDM projects in Asia.}

This paper offers a review of the current position of developing countries in the climate regime and international negotiations based primarily on the analysis of implementation of Clean Development Mechanism (CDM). The paper will place emphasis on changes in national policies to accommodate CDM projects, focussing on the scope and rationale for bottom-up policies and measures as part of development strategies favouring more resilience and sustainability.

Two issues are addressed more specifically: firstly regional specificity among developing areas and notably the pre-eminence of projects located in Asia, and secondly the relevance of CDM projects for both sustained growth and effective mitigation strategies. Regarding the latter, we consider that CDM project multiplication does question the relevance of national policies and the diversity of actors/stakeholders to foster upgraded domestic well targeted development strategies.

Our research considers differences between developing countries and regions regarding selection and implementation of climate mitigation projects- with reference to their GHG emissions and national energy profiles (calculation from Enerdata source and IEA). It refers to selected cases of projects in East Asia - focus on China and Asean countries - showing particular sector selection patterns (differing between semi industrial economies and less developed countries) and diversification of stakeholders for development (role of regional actors within Asia). The analysis is based on international data base of CDM projects (United Nations) and secondary data from IGES (Japan) and Enerdata. The conclusion will examine prospects for CDM in a post 2012 climate régime for developing economies and the future relevance of CDM projects in the framework of Nationally Appropriate Mitigation Actions.

Keywords:

Development policy, climate regime, mitigation, Clean Development Mechanism Projects, sustainability, national climate strategies, Asia, emerging countries. 
Recent trends in world negotiations on climate change have made the new positions of developing countries more conspicuous. Many such countries have indeed shown increased awareness of the topical issues (greenhouse gases (GHG) emissions, carbon intensity of economic growth), stronger commitment to negotiation and proactive attitudes to address both adaptation and mitigation policies in spite of internal rifts within the "group of 77". This paper focussing on some key elements (climate mitigation and the Clean Development Mechanism (CDM)) confirms a specific position attained by developing economies in the climate regime painstakingly established through the United Nation framework, and beyond it suggests that climate policy can indeed be integrated as a component of overall coherent development strategies, taking into account both sustainability and resilience.

The world climate change challenge has generated a new governance or 'global climate regime ${ }^{1}$ - in spite of multiple obstacles ranging from scientific controversies, vested interests and economic lobbying to social and political debates. The foundations of the climate regime consider that developed or industrial countries have been the first and main historical contributors to emissions of Global Heating Gases, particularly throughout the XX th century, and thus have to be at the forefront of the strategies to fight climate change now. This is backed by several international agreements, under UNFCC, and particularly the Kyoto Protocol (1997). Therefore developed countries have a priority to make decisive efforts to reduce their GHG emissions according to their pledges in the Kyoto Protocol ${ }^{2}$ and beyond to muster resources to back-up efforts in developing economies too as these countries lack both finance and technologies. The Clean Development Mechanism was designed to address these challenges. It is one of the flexible instruments implemented by the Kyoto Protocol (note mention others JI ). The CDM enables developing countries to implement climate friendly projects that will bring actual heating gas emission reduction, with decisive financial support from contributors from developed countries that will in turn benefit from credits granted by an international governing system.

Indeed there is much at stake concerning climate change for developing countries, and thus they have adopted a strong standing in the international negotiations. Beyond the instruments, such as the CDM designed for the Kyoto Protocol, the Bali conference (2007), and its roadmap, has placed special emphasis on climate strategies, and particularly for developing countries: their mitigation and adaptation strategies are to be given special support in order to be up to the social and economic dimensions of climate change. Two major challenges have to be faced: first, developing economies claim a 'right to develop', and thus climate policy should not be an additional obstacle to reduction of poverty, satisfaction of basic development needs and increased welfare. On the other hand, they also face the challenge of global sustainability, and thus, adaptation and mitigation objectives are also to contribute to development policies, taking into account specific local conditions regarding actors and priorities.

This paper will review some aspects of developing countries' integration in the climate regime through implementation of the Clean Development Mechanism over the past decade. It will first give an overview of conceptual aspects of CDM as a tool for climate policies in developing countries with contributions from the developed world, and then present trends of emergence of CDM projects. It will place special emphasis on the Asian region that has

\footnotetext{
${ }^{1}$ International regime, i.e., « sets of implicit or explicit principles, norms, rules, and decision-making procedures around which actors' expectations converge in a given area of international relations » (Krasner, 1982, p. 186)

${ }^{2}$ Some major actors such as USA are not part of it! And many countries, such as Russia or Japan are now pressing against its renewal.
} 
become the major host of CDM project in the world (Part I.). Focussing on national mechanism in East Asia, an analysis of project data bases will show that although several countries have been successful at building the framework of national policies to accommodate $\mathrm{CDM}$ projects, there is strong sectoral concentration bias and limited additionality. Beyond CDM there is a need to focus on the new rationale for bottom-up policies and measures to face a possible collapse of the Kyoto Protocol in 2012 and be up to the global climate change mitigation challenge.

\section{The Kyoto Protocol and CDM : Exploring the challenge of the world climate regime for developing countries.}

Admittedly the Clean Development Mechanism, established in the Kyoto Protocol is quite an original and innovative instrument, due to its flexibility and its ambition to integrate developing countries in the climate regime. It is useful to recall basic principles and conceptual issues behind the designing and implementation of CDM. The core concept of additionality is considered as well as the economic efficiency and climatic effectiveness (1.1). Then, reviewing the mechanism's past period of implementation, or take-off stage, empirical data is analyzed to characterize the actual focus of projects as several thousand have been approved. This reveals the geographic and sectorial concentration of projects, and questions the relevance to include all developing countries in the climate regime (1.2).

\subsection{CDM: fundamental principles and governance}

The differentiation between developed and developing countries and their respective contribution to global warming explain the bipolar dimension of the struggle against climate change (Demaze, 2009). The CDM relaxes the commitments of developed countries to reduce greenhouse gas emissions and has the objective to actively integrate developing countries in the climate regime with a financial support. The CDM, defined by the $12^{\text {th }}$ article of the Kyoto Protocol, allows a private actor (e.g. industrialist or investment fund) from a country listed in Annex 1 to finance projects of emission reduction in non-Annex 1 countries. By this way, it can acquire credit of emission reductions (CERs) usable or tradable on the carbon market.

The CDM presents a triple advantage. Firstly, in economic terms, it generates emission reductions at lowest costs in the most economically profitable area, knowing that developing countries usually have a large potential of reduction with low marginal costs (Vieillefosse, 2006). Secondly, in environmental terms, this mechanism associates developing countries in the struggle against climate change thanks to the implementation of clean project (greenhouse gas emissions reductions, improvement of the energy efficiency, pollutant and waste treatment and recovery, use of renewable energy). Thirdly, in terms of development, the CDM favours technology transfers and strengthens sustainable development strategies in developing countries (Borde et al., 2007, UNEP, 2000, Joumni, 2003). The effectiveness of the mechanism is based on the adequacy between these projects and domestic climate strategies/ development objectives (Lecoq et Ambrosi, 2007, Lacour et Simon., 2010).

The additionality issue is probably the most important criteria in the validation process of CDM projects. Its assessment determines the effectiveness and the credibility of the mechanism. The concept of additionality has three dimensions. Firstly, a project must have an environmental additionality: the project's greenhouse gas emissions must be below to what would have happened in the absence of its implementation. The environmental additionality measures the difference between anticipated greenhouse gas emissions in the CDM project 
and those recorded in the baseline (business-as-usual scenario). This double counting of greenhouse gas emissions is central to the acceptance of the mechanism and to the delivery of CERs (Boulanger et alii., 2004). However, the definition of the baseline and, consequently, the assessment of the environmental additionality raises many difficulties (Wanko et al., 2001 ; Boulanger et ali., 2005). The actual reduction in emissions compared to what would have happened without the implementation of the project is difficult to assess. There is no internationally accepted methodology and this lack of technical support is often cited by investors to justify their reluctance to finance projects. If the baseline is defined in too lax an approach, depending on level of emissions based on production technologies available in developing countries, it would lead to fictitious credit emission reductions (Godard et al., 1998). This overestimation of emissions in the baseline could lead to the realisation of 'nonambitious' projects with few environmental gains and could strengthen the so called 'hot air phenomena'. This problem would cause a sharp decline in the international value of permits that would then discourage investment in future research and development activities.

Secondly, the investment additionality of a project means that the CDM must lead to an investment to actually reduce greenhouse gas emissions. The investment should be additional to "what would have happened" in the baseline - thus a way of "proving" the environmental additionality of the project (Boulanger et alii., 2004). Moreover, this principle implies that economic flows in the CDM should not be a substitute for any other flow to developing countries, and particularly to Official Development Assistance (ODA) flows (Organisation Internationale de la Francophonie, 2005).

Finally, the technological additionality means that the allocation of carbon credits must finance the implementation of a technology that would not have been implemented without the use of the CDM (Meunié, 2004; Meunié et al., 2007). The CDM should favour the deployment of environmentally-friendly technologies or cleaning technologies which are still rare in developing countries, because of expensive protection systems (patents and licences) or the relative scarcity of capital domestic resources. Domestic firms should have positive externalities thanks to the implementation of these technologies and new competences in their territory. These technological dimensions and the appropriation capabilities of domestic firms are considered in the approbation process of CDM.

In addition to these initial questionings, we may consider the adequacy of governance for the mechanism. It is an international scheme prescribed by a multilateral environmental agreement but its implementation remains national as it is based on the identification of specific actions and is supervised by administrative regulations depending on domestic development context of recipient countries. Indeed, the governance and the administration of CDM are entrusted to the states, from the definition of priority objectives to the evaluation and registration processes before processing at the international registration level. They have the responsibility to elaborate their climate policy and have to specify a National Designated Authority (DNA) which supervises the CDM. These authorities are free to impose specific supplementary criteria to the implementation of CDM projects. In addition to the level of additionality are also evaluated the environmental impacts of the projects (protection of the local environment), its social externalities (impacts on employment, on low-income groups, on the industrial and regional integration of the project), its economic fallout (balance of payments, cost-effectiveness of the project) and its technological repercussions (contribution to the technological upgrading, innovations and duplication of imported technologies). 
Thus, the institutional appropriation is fundamental for developing countries because there are strong normative and biding commitments (the CDM is designed to operate as a "MRV" scheme - that is: measurable, reportable and verifiable). However, we can question the effectiveness of the mechanism which requires foreign expert intervention, and newly established and reliable public sector framework - whose effectiveness and potential depends on the country's experience or level of development. 


\subsection{CDM implementation: a promising take off with polarization on Asia}

Beyond the difficulties to build a conceptual framework for the CDM, the concrete implementation of the scheme has been more difficult than expected at the international institutional level. This implementation is characterized by strong differentiations, or disparities between regions and countries.

The advantage of the CDM in terms of flexibility for GHG emission reduction commitments for Annex 1 countries explains the substantial growth of projects number since its implementation in 2005, reaching more than 2800 projects registered in the early 2011 (3011 in March) (Graph 1). However, the geographical polarization of the CDM on emerging areas -particularly on Asian countries- limits the scope of the mechanism in terms of integration of developing countries in the climate regime.

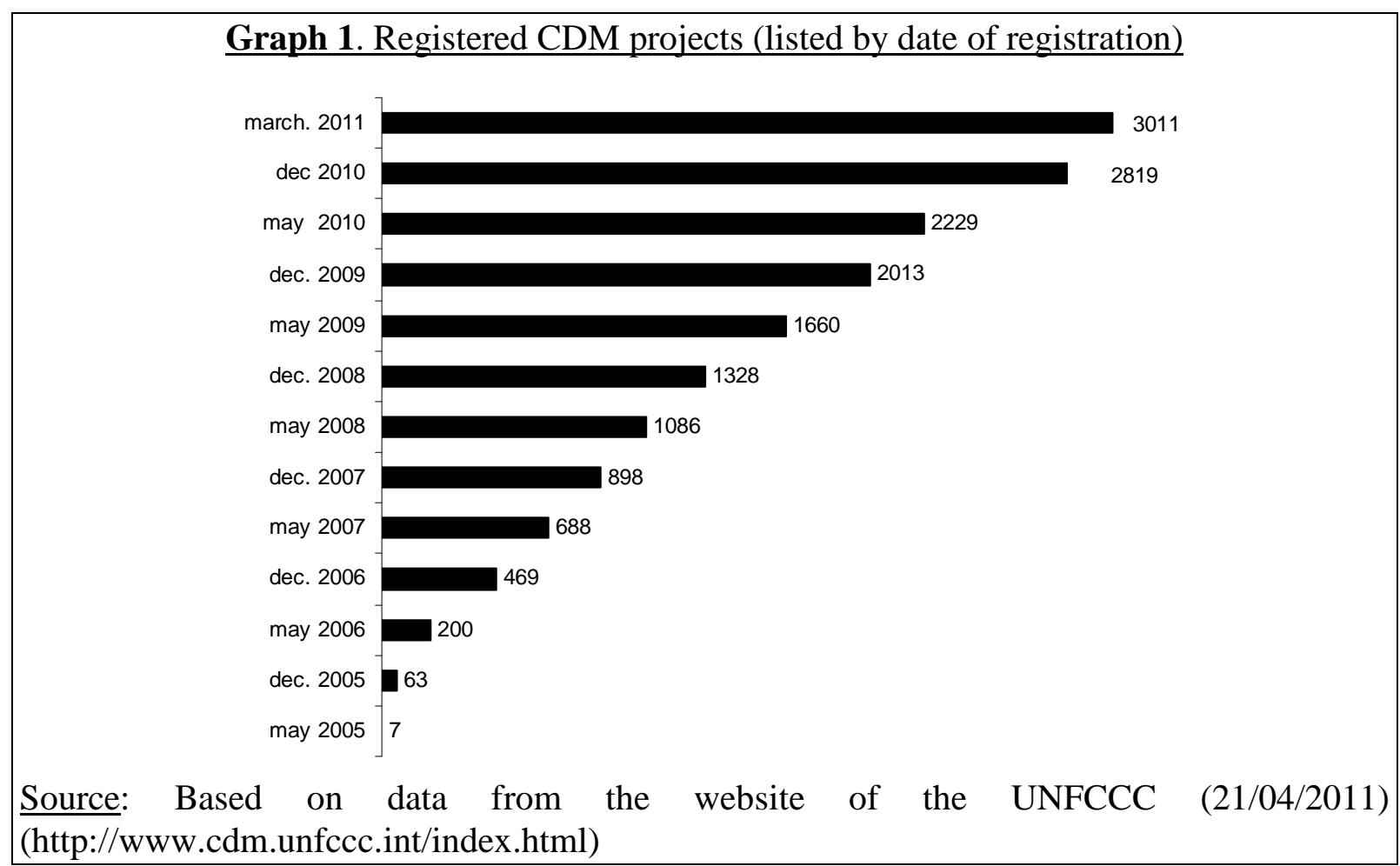

According to official statistics (UNFCCC, April 2011), most of the projects $-65 \%$ of registered project- concern the energy sector (renewable and non renewable source), waste handing and disposal (15\%), and fugitive emissions from fuels ( solid, oil and gas) (5\%). Within the category of renewable energy, according the CDM pipeline elaborated by the UNEP Risoe Center in April 2011 (all categories of registration included), 26\% are hydropower projects, $22 \%$ wind energy, $12 \%$ biomass energy and only $1 \%$ of projects use solar energy. These four sectors of renewable energy are also those who generate the most CERs, representing 43\% of annual CERs and 35\% of credits who should be issued by 2012 (Table 1). 
Table 1. CDM by types of projects - all categories of registrations confounded

(stock - $1^{\text {st }}$ of April, 2011)

\begin{tabular}{|l|cc|cc|cc|}
\hline \multicolumn{1}{|c|}{ Type } & \multicolumn{5}{c|}{ CDM } \\
\hline Hydro & \multicolumn{2}{|c|}{ Number } & \multicolumn{2}{|c|}{ CERs/year (000) } & 2012 CERs (000) \\
Wind & 1603 & $26 \%$ & 178558 & $22 \%$ & 445610 & $16 \%$ \\
Biomass energy & 1324 & $22 \%$ & 117857 & $15 \%$ & 317391 & $11 \%$ \\
Methane avoidance & 741 & $12 \%$ & 47611 & $6 \%$ & 176839 & $6 \%$ \\
EE own generation & 636 & $10 \%$ & 29142 & $4 \%$ & 108494 & $4 \%$ \\
Landfill gas & 471 & $8 \%$ & 57233 & $7 \%$ & 209175 & $8 \%$ \\
EE industry & 325 & $5 \%$ & 48177 & $6 \%$ & 200901 & $7 \%$ \\
Fossil fuel switch & 133 & $2 \%$ & 5210 & $1 \%$ & 18387 & $1 \%$ \\
EE supply side (power plants) & 130 & $2 \%$ & 54411 & $7 \%$ & 179569 & $6 \%$ \\
Solar & 90 & $1 \%$ & 41762 & $5 \%$ & 56199 & $2 \%$ \\
Others & 90 & $1 \%$ & 2479 & $0,3 \%$ & 4747 & $0,2 \%$ \\
Total & 516 & $9 \%$ & 229037 & $28 \%$ & 1045753 & $38 \%$ \\
\hline
\end{tabular}

Source: Based on UNEP (2011) CDM Pipeline 2011, UNEP Risoe Center, Avril (http://cdmpipeline.org/)

The take-off is recent and reveals two joint phenomena. On the one hand, the implementation of the mechanism is supported by several international institutional schemes and mostly national institutions (or Designated National Authority) which have taken time to be established and efficient On the other hand, the acceleration of the number of projects proposed in 2009 reflects the wish to display honourable performances for the Copenhagen Conference, but also probably a relaxation of selection criteria and a windfall for some investors.

When analysing the geographical distribution of CDM projects, it appears that areas with a strong economic development attract the greatest number of projects (Graph 2): Asia Pacific is host to $80 \%$ of registered projects (April 2011), 17\% for Latin America and the Caribbean, whereas only $2 \%$ of registered projects are localised in Africa. CDM projects are polarized on emerging countries because of the coupling between an environmental logic and an economic one, inherent to the mechanism. Although the financial flows mobilised are not quantitatively important, it is essential to highlight a risk of inequalities between developing countries, as we can observe in the case of foreign direct investment (FDI) flows over the past two decades. This unequal distribution of CDM projects can be mostly explained by national differences in the quality of DNA. In least developed countries, these authorities can not provide a technical and methodological support for the elaboration of project design document and for the registration of greenhouse gas emissions in the baseline. Moreover, project size differences explain the differentiation in countries attractiveness; large projects experience lower transaction costs due to the CER accounting (Enttrans, 2007). Finally, the attractiveness of some countries is also due to their economic environment, to the robustness of their infrastructures and regulations towards $\mathrm{CDM}$ and also to their capabilities to secure investments. 
Graph 2. Registered CDM projects by region -

(\% of total world CDM projects stock ; April 2011)

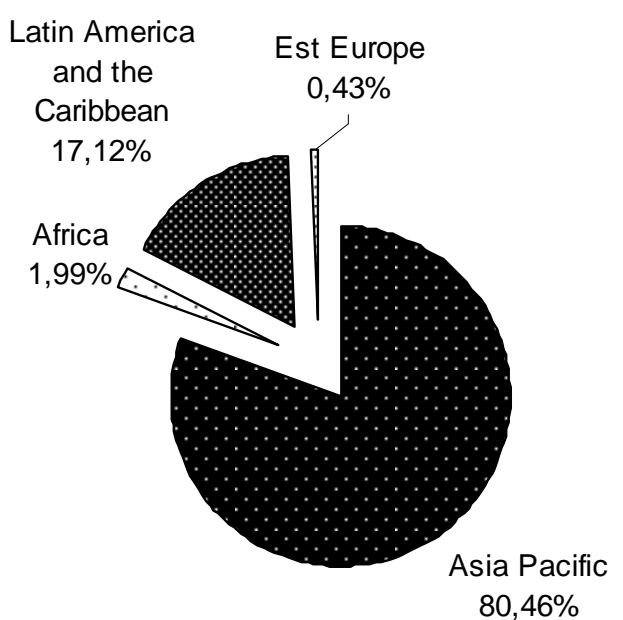

Source: Based on the UNFCCC website (26/04/2011) (http://www.cdm.unfccc.int/index.html)

It is remarkable that China and India are the major beneficiaries of world CDM projects; they attract respectively $44 \%$ and $21 \%$ of registered projects. Their share is predominant in AsiaPacific: 55\% of projects in this region are localised in China and 26\% in India (Graph 3). The leadership of China in world CDM projects can be mostly explained by the institutional framework regulating CDM, the cheap opportunities of emission reductions in its territory and the extended domestic market. Although the CDM has an environmental foundation, this mechanism remains based on the private sector initiative. For example, CDM projects increasing the productive efficiency of a particular good as electricity are also directed by market opportunities (Winkelman et al., 2011). Moreover, the Chinese government has implemented incentive policies that favour the energy sector and technology transfers (Szymanski, 2002).

Graph 3. CDM projects by Asian countries / CERs issued until 2012 by Asian countries (in \% of total in Asia)
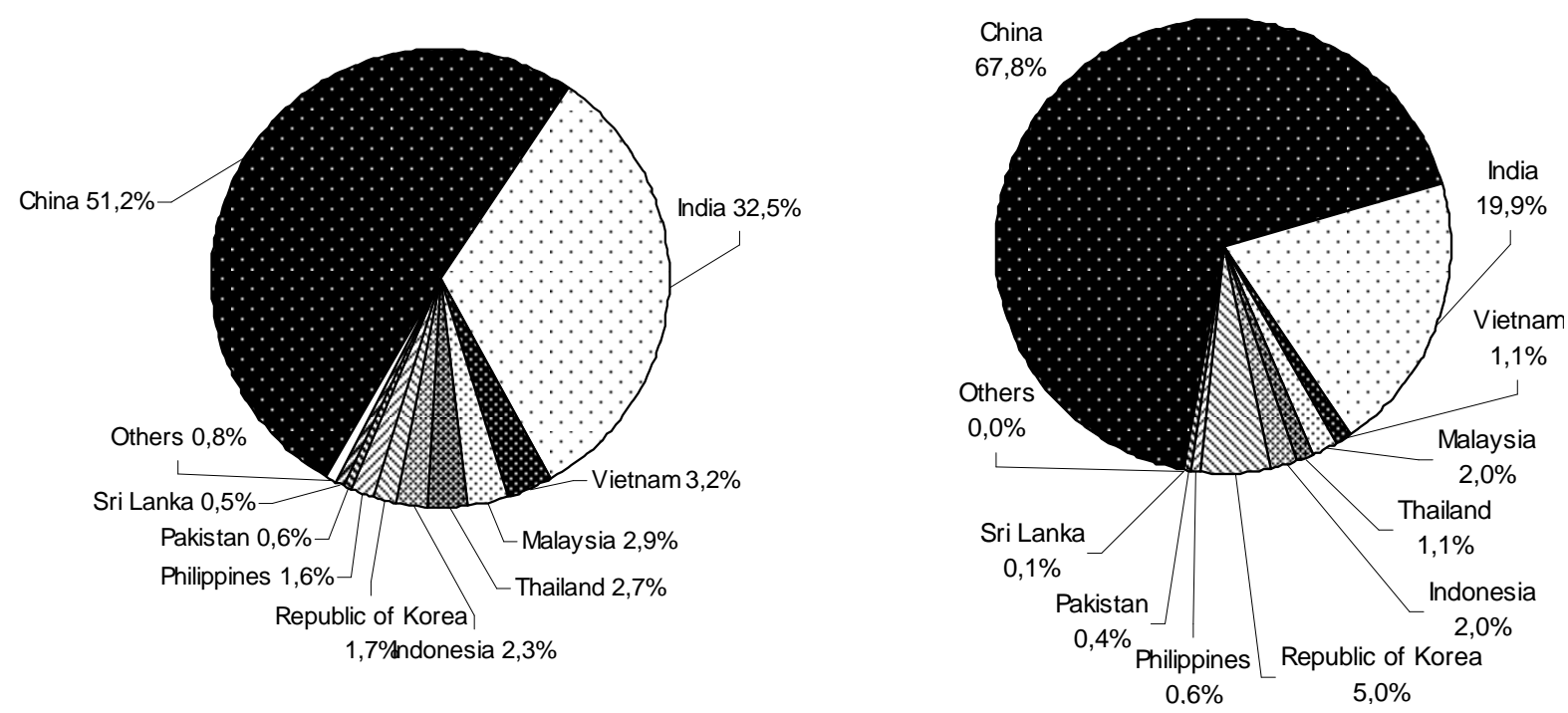

Source: Based on UNEP (2011) CDM Pipeline 2011, UNEP Risoe Center, Avril, (http://cdmpipeline.org/) 
Although they are look less attractive based on sheer numbers, countries such as Vietnam (157 CDM representing 3\% of projects in Asia-Pacific), Malaysia (140 CDM - 3\%), Thailand $(132 \mathrm{CDM}-3 \%)$ and Indonesia $(111 \mathrm{CDM}-2 \%)$ have also been able to take advantage of the mechanism. This is also evidence of their domestic efforts to establish DNA and attract international actors. The polarization of CDM project in Asia-Pacific could also be explained by the active participation of Japan in the mechanism, which is the third world investor by financing $11.5 \%$ of registered projects, behind Switzerland (19.4\%) and United-Kingdom $(23.4 \%)$.

To sum-up, this flexibility mechanism of the Kyoto Protocol had initially the advantage to be beneficial for both parties. The CDM was labelled the "win-win mechanism" at the Kyoto Conference but after 6 years of implementation it appears that its pertinence in terms of integration of developing countries in the climate regime is limited. It favours North-South cooperation and relaxes the quantitative commitment of developed countries, but the mechanism remains marginal for most of developing countries. The issue of technology transfers and absorption capacities of developing countries remains important. Deep differences have emerged between developing countries. Finally, the definitions of the environmental additionality and the baseline constitute a set of difficulties which weaken the efficiency of the mechanism, explaining why the least developed countries are in fact excluded. 


\section{$\underline{\text { 2. CDM in action : an investigation focussing on East Asia }}$}

The Asian region is well worth special attention as we find that climate policies there are based on a double dynamism: on the one hand these domestic policies reflect commitment to international negotiations for the climate regime but they also correspond to a growing concern for sustainable development policies that place a special emphasis on the environmental/energy/climate package. National climate policies in emerging Asian economies do result from a set of three forces which bear upon the design of national development strategies: Firstly the energy constraint as demand shows a steep increase over the past decades translating into higher market instability risks, heavier import costs. Secondly the environmental constraint with increasing issues of deforestation, soil degradation, water resources, land use and thirdly the socio-ecological constraint when risks and costs are unevenly shared by various groups of societies, and conflicts tend to multiply.

We will investigate here how the CDM projects come to be integrated in the global picture of development trends in East Asia/Southeast Asia, and particularly national strategies. We will consider first the global emissions reduction challenge (2.1) and then contrasting characteristics of CDM project implantation in various countries (2.2). Finally we will discuss limits and criticisms of CDM and prospects beyond the 2012 milestone with the expiration of the Kyoto Protocol.

\subsection{The East Asian region : a challenging area for proactive climate policies}

Asia as a whole is known to be particularly vulnerable to climate change as many countries and their people depend on activities such as agriculture, fisheries or even tourism that are sensitive to changes and hazards produced by climatic events (Reddy, 2009). East Asian countries because of their vigorous growth over four decades display notable differences in their GHG emission levels as well as their energy intensity and the energy consumption per capita (Graph 4 and 5). It is both understandable and remarkable that many countries throughout Asia have taken a strong stand in favour of international climate negotiations and at the same time steadily built policy instruments to address national issues (WRI-IFC, 2009). This position can bring credibility in to climate regime and strengthen negotiating position (seen Copenhagen conference of Parties or COP15 in 2009). It can also facilitate anticipation and mobilization of both international and domestic resources to fight consequences of climate change and promote mitigation.

It is relevant to consider separately the 'continent -country' that is China. It is now the largest GHG emitter in the world (20\% of world total versus less than $5 \%$ for India) although its carbon intensity is on a downward trend. Considering growth of activities and population too, this is going to last well until the middle of XXIst century, and due to increasing energy needs it may be difficult to 'decarbonize' economic growth at a sustained rate in the coming decades (Zhang Zhong Xiang 2009). At present industry and the electricity sector are the major $\mathrm{CO}_{2}$ emitters - electricity $42 \%$ of total and industry $25 \%$. The electricity sector will remain a major source of emissions due to large share of coal fire plants and uncertainty regarding nuclear plant further development. Contrary to what is observed in more developed countries like Japan or Korea, transports and residential and tertiary sectors still make a small contribution to emissions (about $5 \%$ each in 2009). This energy emission challenge has influenced the CDM strategy to a large extent (see next section 2.2).

Turning next to ASEAN member countries, they present a diversity of situation. As a whole ASEAN average is well below world average carbon intensity ( 0.40 versus 0.42$)$, and carbon 
intensity has declined over the past decade. But the quantity of carbon emission is clearly on an upward trend.

Newly industrialized countries (NICs) in ASEAN display the highest carbon intensity, but it has taken a slowing down or even decreasing trend over the past fifteen years. This remains to be confirmed but could be a sign that their growth becomes less carbon emission intensive obviously elements such as slowing down of economic growth and changes in sector proportion also have to be taken into accounts. But clearly ASEAN NICs are already substantial emitters, especially by developing countries standards, whereas the three less developed countries - Burma/ Myanmar, Lao and Cambodia remain very small emitters (and this is reflected in small numbers of CDM projects too). Recent estimates, on comparable basis, suggest that the five more advanced economies emit between 70 MT (Philippines) and 350 MT (Indonesia) (see table in Annex 1 and 4). Singapore would stand around 34 MT. Burma would be around 7 MT and Lao and Cambodia below 4 MT CO2.

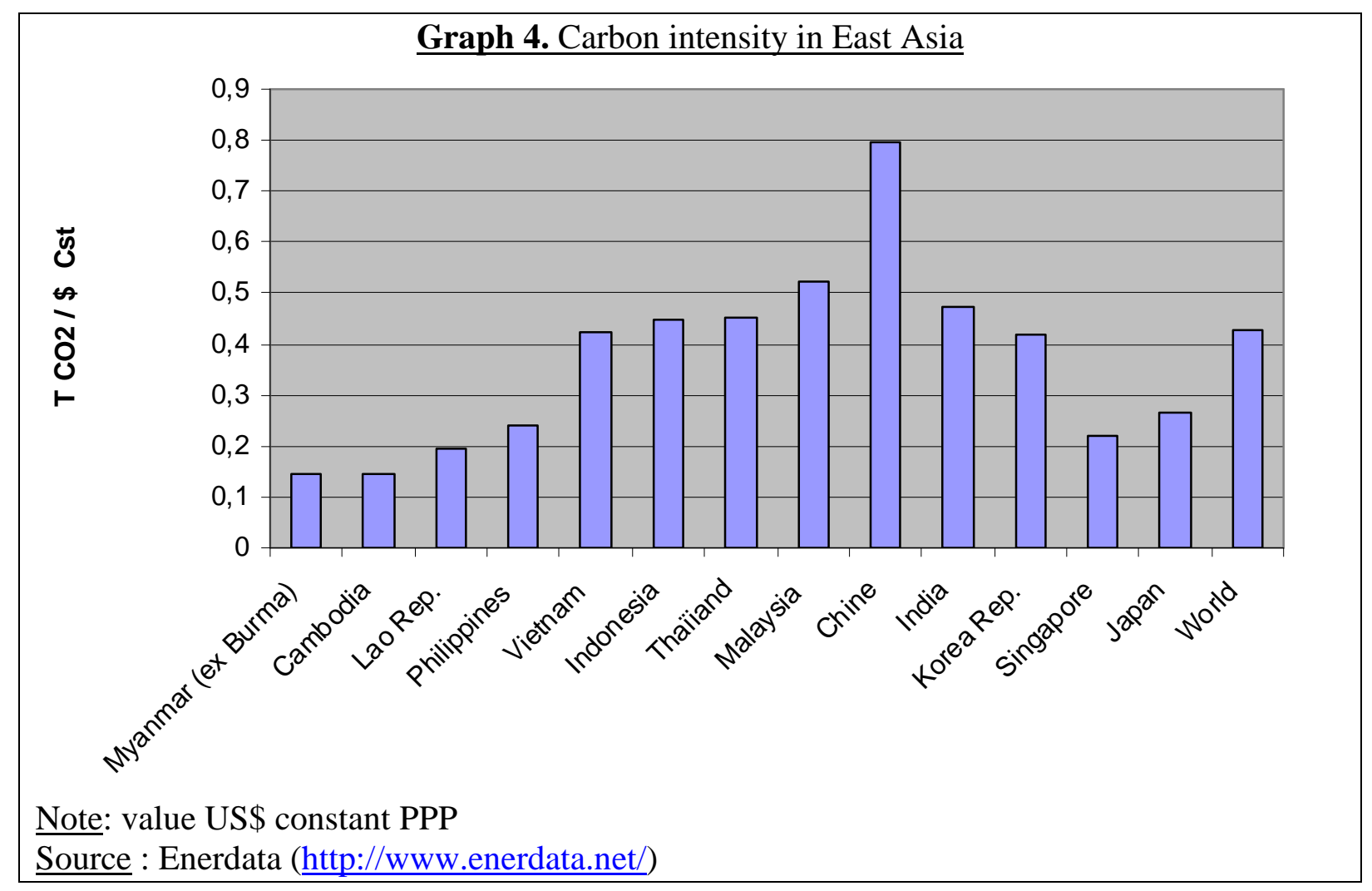

On a sectorial basis, apart from the energy sector, emissions in ASEAN NICs originate first from industry and transport -whereas residential and agriculture remain at lower rank (see Annex 3). It is also remarkable that industries that are energy and emission intensive have already been subjected to targeted policies (part of national energy strategies) and promotional measures to steer them towards lower emission activity3. It is worth mentioning that energy policies have been actively promoted since the early 1980's when emerging Tigers started to bear the brunt of higher energy intensity and steep price shock on the world energy markets. This dual challenge of energy and climate has been perceived by countries and regional bodies as it requires both national policies and regional cooperation (ESCAP 2007). Several NICs of Southeast Asia have designed and implemented national climate action plans over the past decade.

\footnotetext{
${ }^{3}$ This has frequently been the case for cement, construction material, glass and even automobile and electronics.
} 


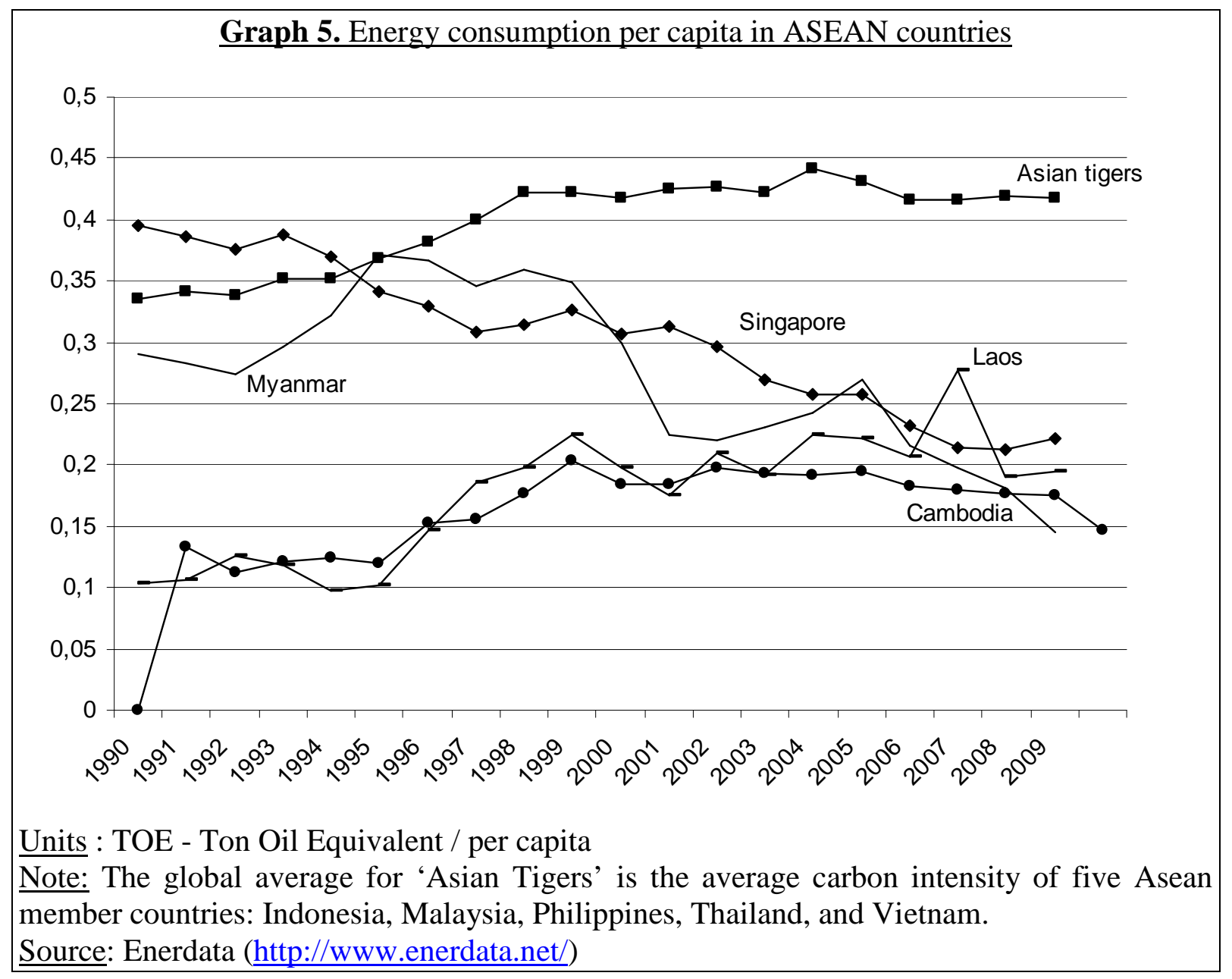

For Southeast Asia as a whole, the challenge of emissions originating from agriculture and forestry is to be considered separately: they are determined by transformation of agricultural and forestry systems, and current trends in socio-economic dynamics. In these areas carbon emission control and reduction -because of their magnitude and some controversial aspects too - are beyond the scope of CDM itself - the REDD ${ }^{4}$ scheme is specifically designed to address them. It is telling that several countries have from the start excluded agricultural and forestry from the scope of CDM projects.

\footnotetext{
${ }^{4}$ U.N.Programme Reducing Emissions from Deforestation and Forest Degradation in Developing Countries.
} 


\subsection{CDM projects in national contexts in East Asia; Contrasting approaches.}

East Asia is indeed facing a major challenge to curb down emissions - and as seen above energy intensity too has to be kept under control. This sets the framework for CDM projects selection and development in a region which has taken a world leadership but also offers interesting cases: States have adopted a proactive attitude in many countries to establish and operate their DNA. In several cases domestic policy on CDM project targeting has been tailored to fit national ambitions for climate sensitive and sustainable development.

\section{CDM in East Asia: an overview by sector}

A major feature of CDM projects overall stock is their focus on the energy sector throughout the East Asia region - this sector represents/amounts to about $75 \%$ of all projects. This is slightly below the world average presented in table 1 (90\% of all world projects are energyoriented). In fact there is a large diversity of project format or size and sub-activities represented covering about 25 areas or economic activities emitting global heating gases (CO2 and others). CDM projects are conspicuously absent or marginal in the transport and residential sectors: this can be due to lack of motivation from private sector initiative and also to other sources of finance (e.g. Climate Technology Fund of the World Bank for national and local government initiatives). They also concern indirectly agriculture (use of waste for energy, production of biofuels).

The focus on the energy sector is indeed telling : sustained growth and industrialization has triggered a crave for energy which in turn make the sector a prime target for mitigation actions. In addition, one may consider that developmental States in East Asia are seeking a double windfall by promoting CDM actions concerning energy (graph 6) : they can seek net financial gain on emission reduction (thus co-financing profitable projects in exchange of emission reduction certificates) and promote energy efficiency - as the additionality proves to be quite a volatile concept.

Considering the energy generation activities hydro power and wind power take the lead; obviously hydro power can capitalize on hitherto untapped small scale projects, and an historical tradition to master large watershed areas. Wind power electricity has benefitted from commercial promotion of new generators technologies on large scale - but there is a controversy about technological dimension and incentive of CDM in this respect! This is particularly true for India and China that host more than $80 \%$ of all projects in Asia. 


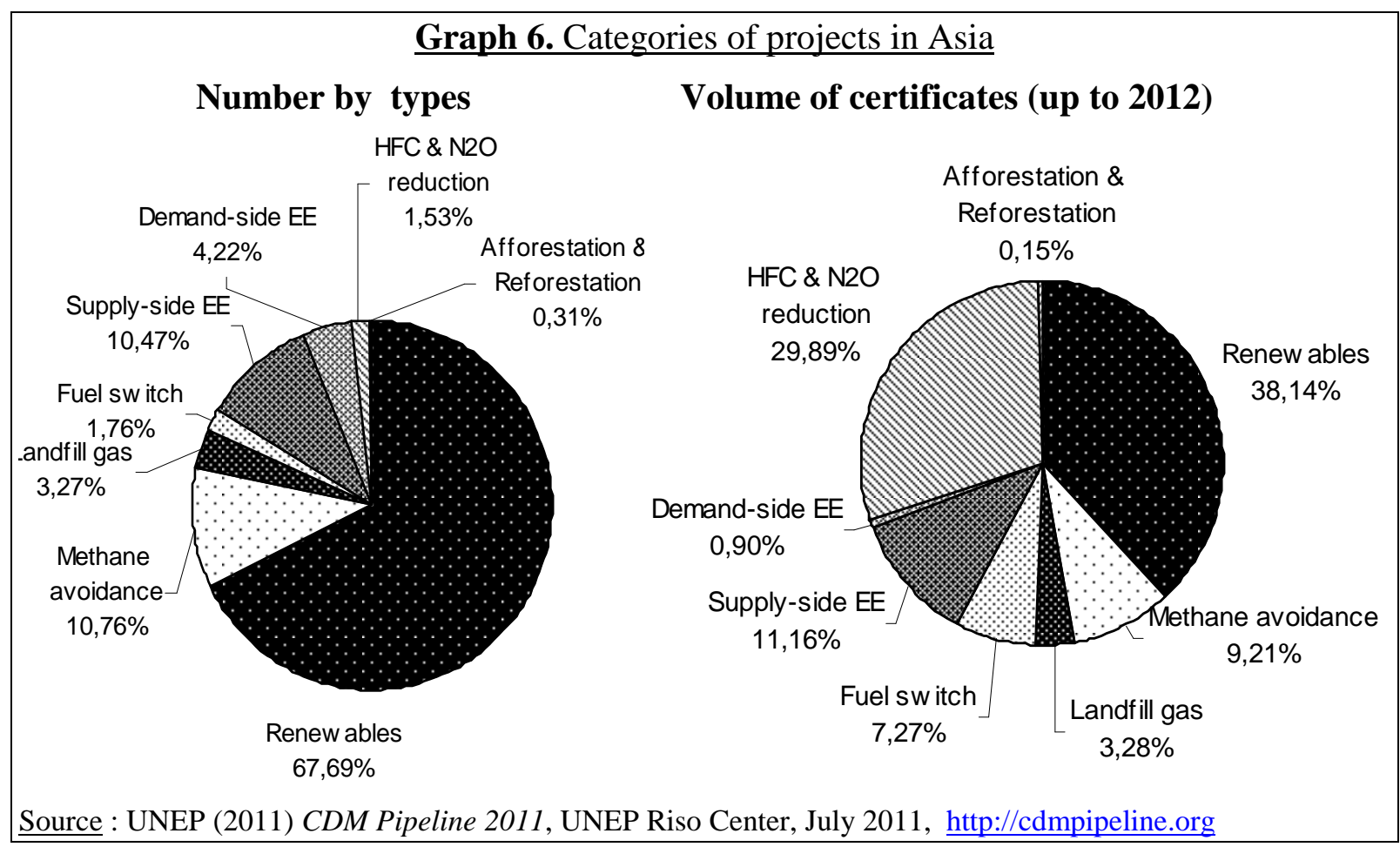

Beyond production of renewable energy, some less glamorous activities are testimony of the many untapped opportunities for reduction of $\mathrm{CO}_{2}$ emissions and of a burgeoning drive towards low carbon economy: projects promoting energy efficiency, use of waste and biomass, represent about $25 \%$ of all projects presented at DNAs.

In the energy sector a large majority of projects (about 60\%) have been selected because of easy investment and financial returns - therefore the additionality comes into debate. This is confirmed by the fact that really innovative projects based on sea power or geothermal source seem to be very few and far between.

\section{Going through selected national cases}

China has indeed /made the most out of mobilizing CDM projects to serve its own priorities in terms of energy and climate policies

The State - at the central and local government level too - has taken special measures to establish bodies and promote institutional network to foster projects throughout national territory, in line with targets of the $11^{\text {th }}$ national Plan. Priority is given to energy saving measures, reduction of energy intensity and use of renewable energy (Enttrans, 2007). As a result we find that $44 \%$ of nationally approved projects concern hydro power, $29 \%$ wind power, and $12 \%$ aim at improving energy efficiency and energy saving in various industries.

Beyond the strict policy framework, targeting of CDM projects was supported by an innovative system of taxation on emission reduction certificates, depending on the project characteristics (Reddy, 2009). Thus projects that focus on renewable energy, reforestation or methane capture are subject to a $2 \%$ tax on certificates whereas there is a $65 \%$ tax on projects concerning emissions of polluting gas (such as HFC or PFC). The rationale for this is to favour long term projects for investors rather than easy gains at low marginal costs.

Turning to ASEAN member countries, all five large countries (the NICs or so-called 'tigercubs'!), have made inroads to host between 50-90 projects of various magnitudes and sectors. Public policy in Indonesia has shown a dual attitude - on the one hand emissions related to agriculture and deforestation are still a very politically sensitive issue - they also make it the 
biggest emitter - and thus difficult to deal with, on the other hand State agencies have taken a proactive attitude to promote CDM projects as part of a new wave of development initiatives; this has resulted in selection of the largest diversity of project types among Asean countries.

Thailand for its part has experienced a slow start, with ambiguous positions at first. Over the past years it hase made up for lost time and promoted CDM project as a complement of its well publicized energy policy (and just completed climate masterplan !). TGO, the DNA of Thailand has indeed followed in the steps of the Ministry of Energy and approved $60 \%$ of energy related project (mostly biogas and methane and very few based on hydo and wind power).

Vietnam may be a special case; either because of political conservatism or on an opportunistic basis, it has given hydro electricity top priority and claims it also embodies technology transfers.. Hydro power represents $70 \%$ of all projects, with most equipments imported from China (Nguyen et alii., 2010).

Less developed countries, namely Lao, Cambodia and Burma, have managed to promote more than ten projects each. They have selected them to complement traditional development projects as they do not have yet major domestic emissions constraints. In addition they do not face substantial energy resource problems (due to still low intensity and also large resources of renewable for Laos and oil/gas deposits for Burma and Cambodia). They have benefited from intervention from bilateral development agencies and proactive consulting firms too.

\subsection{Policy challenges: scope for sustainability and resilience?}

Considering the innovative approach taken and the limited time frame there are unquestionable achievements over the past 6 years of CDM implementation. In purely quantitative terms there has been a sprouting of projects, in line with earlier expectations (Rhama et alii., 2010). The flexible approach is well reflected in the diversity of situation, but it is also the source of a set of difficulties and issues that need to be addressed.

There is still a great deal of debate about additionality. In many instances, as mentioned above, energy generation projects are well in line with earlier trends and equipments approved in CDM project do not differ from other national programmes. Additionality can also be faked or a misleading criteria (Aldy et alii, 2010). Similarly some energy saving projects do not justify MDP framework as they could also be triggered by changes in the domestic prices system (Vöhringer et alii., $2010 \mathrm{p} \mathrm{11).} \mathrm{We} \mathrm{will} \mathrm{not} \mathrm{discuss} \mathrm{here} \mathrm{the} \mathrm{issue} \mathrm{of} \mathrm{markets} \mathrm{for}$ emission certificates: it is still controversial because of evaluation and certificate problems over the past three years. It is also theoretically complex issue because it involves countries with binding commitments (and with other tools to experiment such as carbon tax) and developing countries uncommitted until 2012 (see Timilsina, 2009).

Secondly, and more to the point of relevant climate strategies, technology transfer is becoming a genuine issue - although data is still sparse. Some areas have been ignored in domestic criteria and project selection (transports, sea wave power, geothermal...). Many reports point out the lack of technology upgrading in many projects and the potential for substantial improvement (Forsyth, 2009, Flamos, 2010, UNFCC 2010 p.22, Glachant et al., 2011).

Thirdly, many analysts criticize the multiplication of small scale projects, with limited investment in too few sectors: this would make them irrelevant to initiate genuine climate mitigation. On the other hand the spreading of projects and the many local and international actors that have committed themselves to go though the formal process is evidence of a new 
dynamics. In several ASEAN countries there is now a base to build upon and some genuine experience to capitalize on in order to draw prospect beyond the 2012 deadline.

Finally, the theme of social and local development impact of project is still being debated. In most instances, social impact of project is part of the criteria for project approval by national authorities; but it seems that there are substantial discrepancies both within countries depending on project types and between countries in terms of stringency of social criteria. In that respect the sustainable development label is awarded too easily and CDM project show too much variation across countries (Disch, 2010).

\section{Prospects: CDM as an element of broader climate policies}

The trend over the past year does not show a decrease in number of projects which could mean there is still a substantial amount of confidence in the mechanism in spite of the forthcoming termination of the Kyoto Protocol.

The debate is still vivid about CDM projects that can be seen as speculation from LDCs to cheaply develop infrastructure and energy sources, more than tool for sustainable development. In addition the volume of certificates, relative to emissions levels in industrialized/developed countries remain modest or negligible.

A more optimistic conclusion would consider CDM as one flower in the bunch of climate strategy tools; CDM projects have come to boost domestic efforts in the field of energy diversification. Together with periodical environment damages that ignite news headlines awareness and concern, CDM projects make climate change mitigation strategies part of domestic debates and national priorities. In that respect they could be seen as a first step towards building a comprehensive framework, in line with the principle of NAMAS (Nationally Appropriate Mitigation Actions -see Ecofys 2011) that is likely to be at the core of renegotiation of the extension or renewal of the Kyoto Protocol. 
ANNEX 1. Estimation of total CO2 emissions in selected Asian countries 2009

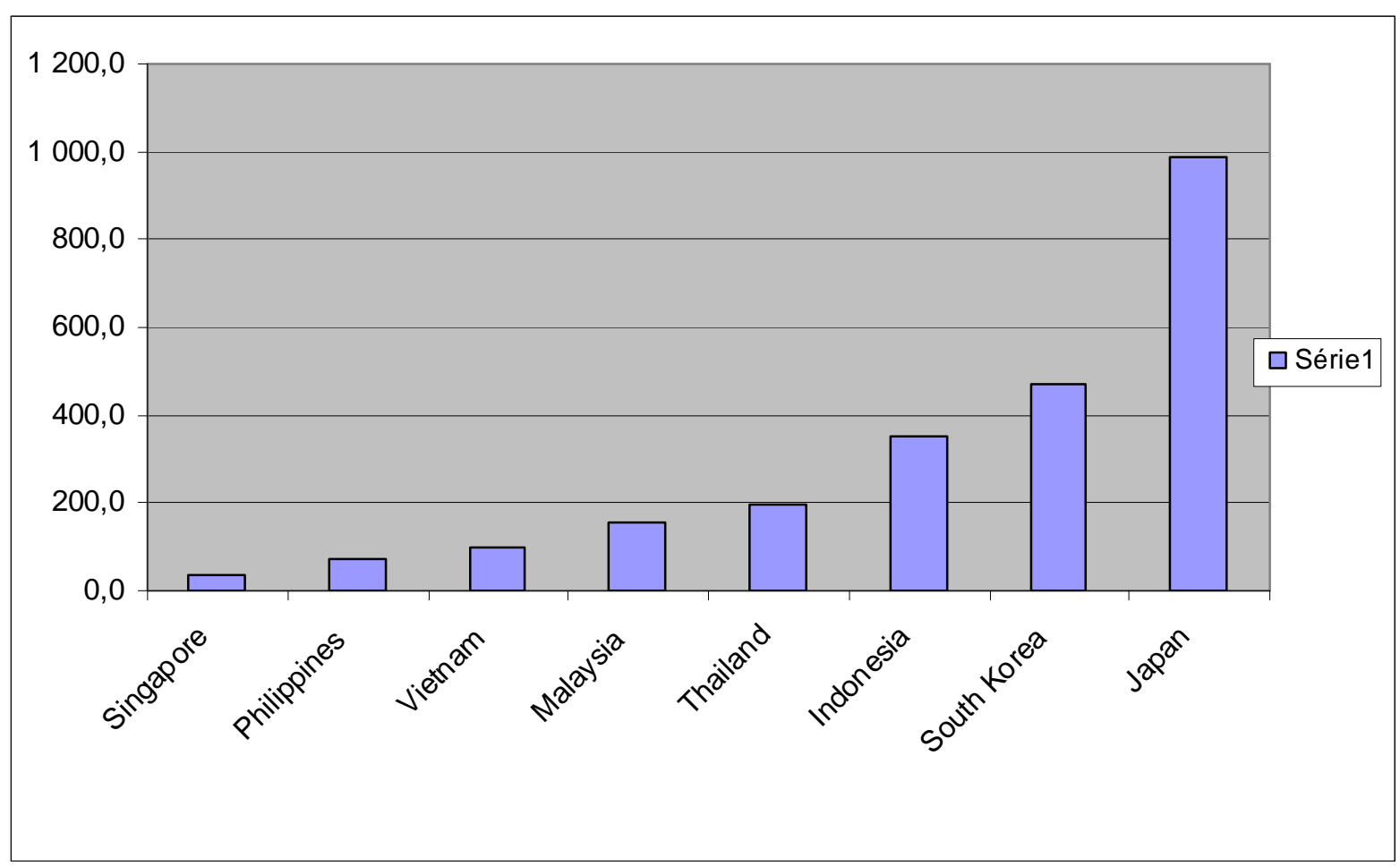

Unit : Million Metric Tons of CO2

Source: Enerdata

\section{ANNEX 2. Energy intensity for some ASEAN member countries}

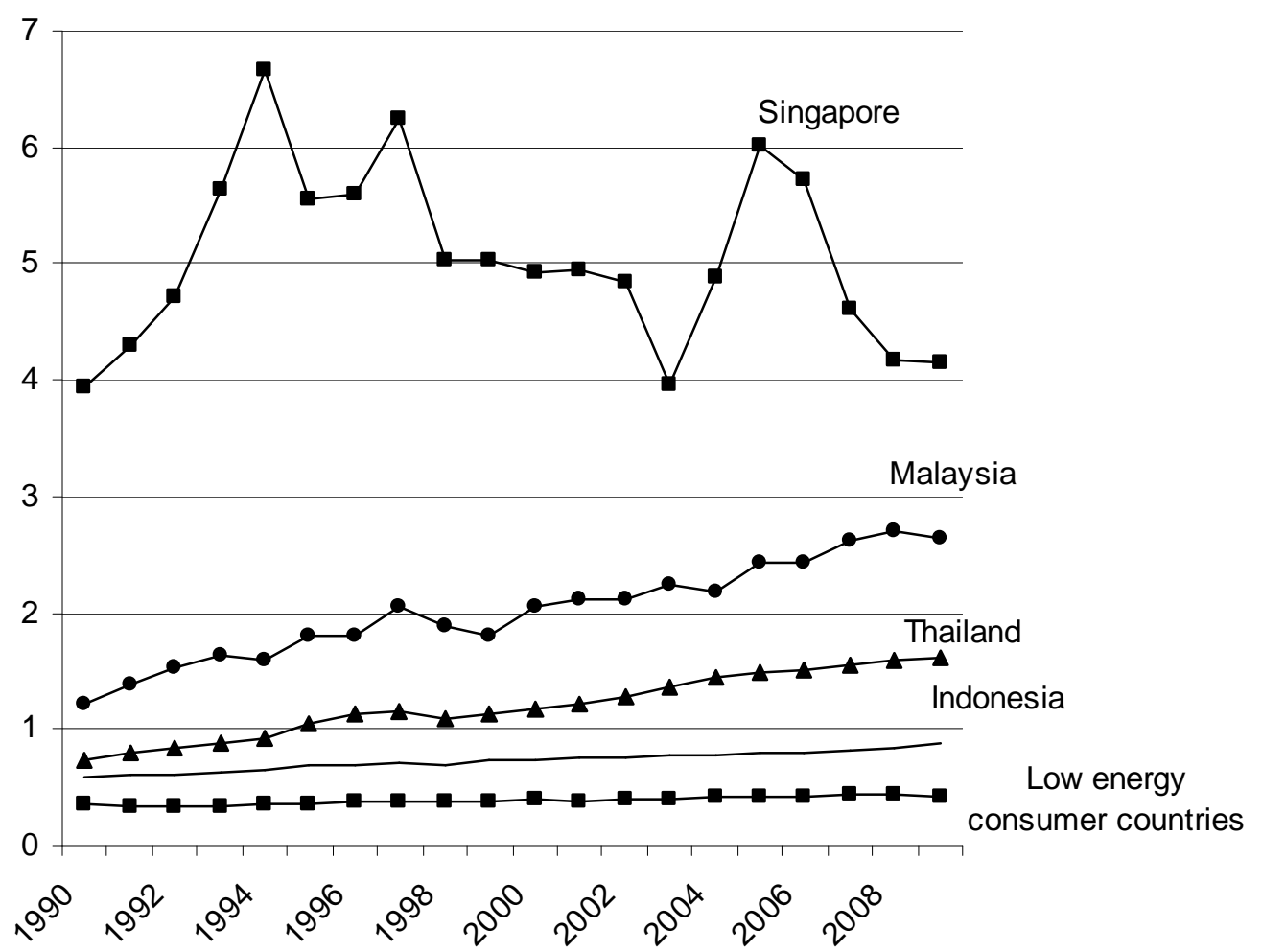

Unit: Mtoe / per GDP unit

Source: Enerdata 
ANNEX 3. Emissions by sectors in 2009

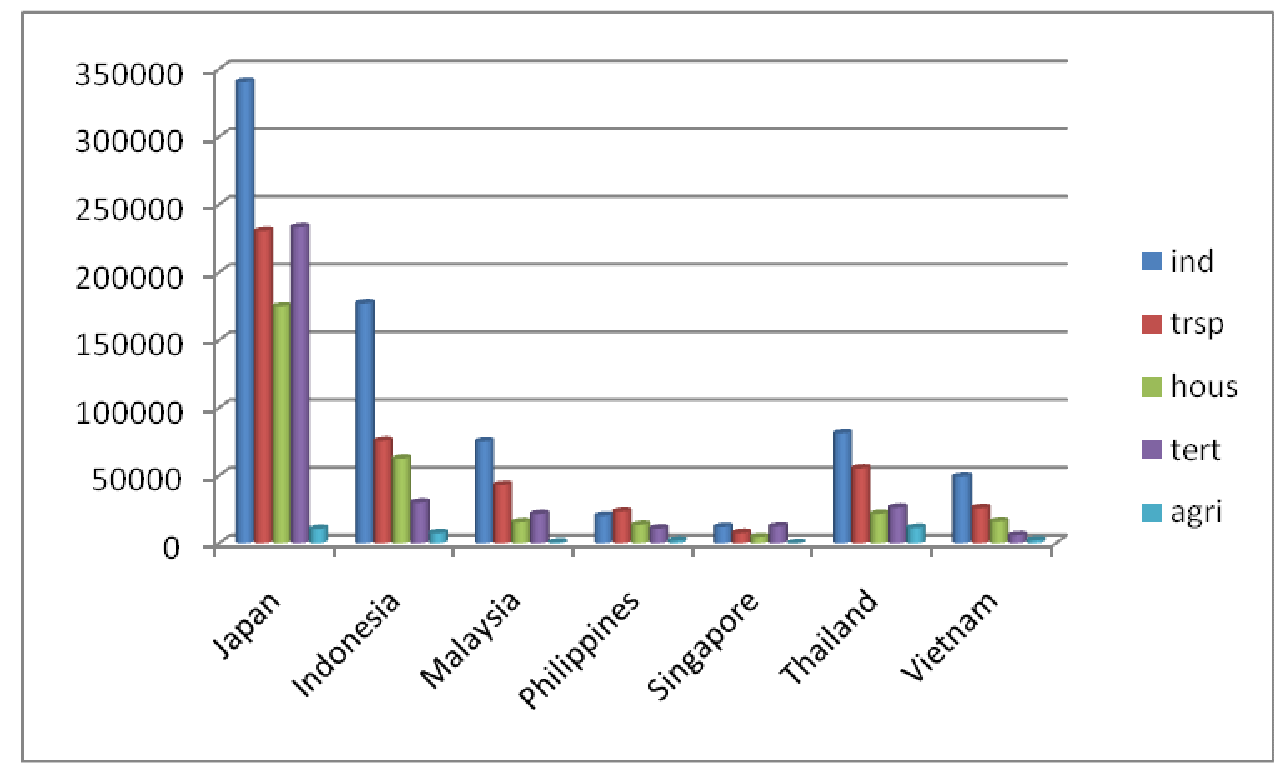

Unit: Ktoe

Source: Enerdata

ANNEX 4. Indicators for countries and regions, 2008

\begin{tabular}{|c|c|c|c|c|c|c|c|}
\hline $\begin{array}{c}\text { Country / } \\
\text { Region }\end{array}$ & $\begin{array}{c}\text { Pop. } \\
\text { (millions) }\end{array}$ & $\begin{array}{c}\text { GDP } \\
\text { PPP } \\
\text { (billion } \\
2000 \\
\text { USD) }\end{array}$ & $\begin{array}{c}\underset{(1)}{\mathbf{C O}_{2}} \\
\text { emissions } \\
\left(\mathrm{Mt} \text { of } \mathrm{CO}_{2}\right)\end{array}$ & $\begin{array}{l}\text { Share in } \\
\text { world } \\
\text { emissions }\end{array}$ & $\begin{array}{l}\text { TPES } \\
\text { (Mtoe) }\end{array}$ & $\begin{array}{c}\mathbf{C O}_{2} / \\
\text { GDP PPP } \\
\left(\mathrm{kg} \mathrm{CO}_{2} /\right. \\
2000 \text { USD) }\end{array}$ & $\begin{array}{c}\mathbf{C O}_{2} / \\
\text { Pop. (t } \\
\mathrm{CO}_{2} / \text { capita) }\end{array}$ \\
\hline Cambodia & 14.70 & 45.78 & 4.60 & $0.02 \%$ & 5.22 & 0.10 & 0.31 \\
\hline China & 1333 & 11054 & 6550 & $22.29 \%$ & 2131 & 0.59 & 4.92 \\
\hline Sth Korea & 48.61 & 1139.3 & 501.27 & $1.71 \%$ & 226.95 & 0.44 & 10.31 \\
\hline Indonesia & 228.25 & 897.90 & 1385.38 & $4.72 \%$ & 198.68 & 0.43 & 1.69 \\
\hline Japan & 127.69 & 3597.6 & 1151.14 & $3.92 \%$ & 495.84 & 0.32 & 9.02 \\
\hline Malaysia & 26.99 & 303.78 & 180.87 & $0.62 \%$ & 72.75 & 0.60 & 6.70 \\
\hline Philippines & 90.35 & 445.54 & 72.34 & $0.25 \%$ & 41.07 & 0.16 & 0.80 \\
\hline Singapour & 4.84 & 138.49 & 44.31 & $0.15 \%$ & 18.52 & 0.32 & 9.16 \\
\hline Thaïland & 67.39 & 564.09 & 229.47 & $0.78 \%$ & 107.20 & 0.41 & 3.41 \\
\hline Vietnam & 86.21 & 283.45 & 102.96 & $0.35 \%$ & 59.42 & 0.36 & 1.19 \\
\hline$\overline{\text { USA }}$ & 304.53 & 11742 & 5595.92 & $19.05 \%$ & 2283 & 0.48 & 18.38 \\
\hline India & 1139.97 & 4310.3 & 1427.64 & $4.86 \%$ & 620.97 & 0.33 & 1.25 \\
\hline OECD & 1190 & 32868 & 12630 & $42.99 \%$ & 5422 & 0.38 & 10.61 \\
\hline Asia ${ }^{(3)}$ & 2183 & 8760 & 3023 & $10.29 \%$ & 1410 & 0.35 & 1.38 \\
\hline World & 6688 & 63866 & $29381^{(2)}$ & $100 \%$ & 12267 & 0.46 & 4.39 \\
\hline
\end{tabular}

Notes: (1). CO2 emissions from fuel combustion only. Emissions are calculated using the IEA's energy balances and the Revised 1996 IPCC Guidelines. bunkers.

(2) $\mathrm{CO} 2$ emissions for world include emissions from international aviation and international marine

(3) Data for Asia, China excluded

Source: International Energy Agency, 2010, Key World Energy Statistics, Paris. 


\section{Abstract in French}

\section{TITRE : Quelle intégration des PED dans le régime climatique ? Le Mécanisme de Développement Propre en Asie.}

\section{Résumé}

A partir d'une analyse de la mise en œuvre du Mécanisme de Développement Propre, ce papier vise à préciser les modalités d'intégration des pays en développement dans le régime climatique, et en particulier à mettre en évidence une différenciation entre les pays, entre les grandes régions. Ceci permet de s'interroger sur deux aspects peu évoqués jusqu'à présent : d'une part la possible dimension régionale dans les politiques climatiques nationales et internationales et d'autre part la pertinence des projets MDP face au défi d'une bonne articulation entre les efforts des politiques climatiques et la soutenabilité des stratégies de développement. Ces aspects sont analysés plus particulièrement dans le cas de pays d'Asie du sud-est (économies semi-industrialisées et pays moins développés de l'ASEAN). Finalement, on s'interroge sur les enjeux de la transition du régime climatique dans une perspective post-2012.

Mots-clés : pays en développement, pays émergents, régime climatique, politiques climatiques, politiques d'atténuation, mécanisme de développement propre./ 


\section{$\underline{\text { References }}$}

ALDY J.E. et alii, 2010, Designing Climate Migitation Policy, Journal of Economic Literature, Vol.48, $\mathrm{N}^{\circ} 4$, pp.903-934

BORDE A., JOUMNI H., 2007, Le recours au marché dans les politiques de lutte contre le changement climatique, Revue International et Stratégique, Tome 3, n67, 53-66.

BOULANGER P.M., LUSSIS B., BRISME C., HUPPEN L., BRECHET T., GERMAIN M. et GRANDJEAN G., 2004, Le Mécanisme pour un développement propre : conception d'outils et mise en auvre, Plan d'appui scientifique à une politique de développement durable (PADD II) ; Politique scientifique fédérale, janvier.

BOULANGER P.M., BRECHET T. et LUSSIS B., 2005, Le Mécanisme pour un développement Propre tiendra-t-il ses promesses, Reflets et Perspectives, Tome XLV, $\mathrm{n}^{\circ} 3,5-27$.

DEMAZE M.T., 2009, Le Protocole de Kyoto, le clivage Nord-Sud et le défi du développement durable, Espace Géographique, Vol.2, Tome 38, 139-156.

DISCH D. A., 2010, "Comparative analysis of the 'development dividend' of Clean Development Mechanism projects in six host countries" Climate and Development, Volume 2, Number 1, 2010 , pp. 50-64(15) Earthscan

ECOFYS, 2011, Cancún results pave the way for Nationally Appropriate Mitigation Actions [NAMAs], Policy Update, $\mathrm{N}^{\circ} 2$, April.

ENTTRANS, 2007, Promoting Sustainable Energy Technology Transfers through the CDM : Converting from a Theoretical Concept to Practical Action, European Union Sixth Framework Programme, Project: The Potential of Transferring and Implementing Sustainable Energy Technology through the Clean Development Mechanism, Janvier 2006- Décembre 2007.

ESCAP- UN, 2007, ASEAN 10 as One Challenges and opportunities for Asean integration, Bangkok. 74p.

FLAMOS A., 2010, The clean development mechanism, catalyst for widespread deployment of renewable energy technologies? Or misnomer? Environment Development and Sustainability, Tome $12, \mathrm{n}^{\circ} 1,89-102$

FORSYTH T. 2007 Promoting the Development Dividend of Climate Technology Transfer. World Development Vol. 35, No. 10, pp. 1684-1698, 2007

GALHARETT S., 2010, "Le marché carbone comme soutien à la transition », Document IDDRI $2 / 2010 ; 24 p$.

GLACHANT M., MENIERE Y., 2011, Kyoto Project Mechanisms and Technology Diffusion, Environmental and Resource Economics [under print].

GODARD O., HENRY C. (1998) Les instruments des politiques internationales de l'environnement: la prévention du risque climatique et les mécanismes de permis négociables, Rapport au Conseil d'Analyse Economique, Publié in D. Bureau D. et alii (dir.) Fiscalité de l'environnement, Paris, La Documentation Française, Rapports du CAE, Juillet, pp. 83-174.

International Energy Agency (2009) Key World Energy Statistics, Agence Internationale de l'Energie (http://www.iea.org/publications/free_new_Desc.asp?PUBS_ID=1199) 
JOUMNI H. , 2003, Les perspectives de mise en œuvre du Mécanisme de Développement Propre : enjeux et contraintes, Cahiers du GEMDEV, n²9, Octobre, pp. 95-115.

KRASNER S.D., 1982, Regimes and the limits of realism: regimes as autonomous variables, International Organization, Vol. 36, $\mathrm{n}^{\circ} 2$, printemps.

LACOUR P., SIMON J-C., 2010, Quelle intégration des PED dans le régime climatique ? Le Mécanisme de Développement Propre en Asie, XXVIe Journées Tiers Monde. BETA/Université de Strasbourg.

LECOQ F. et AMBROSI P., 2007, “The Clean Development Mechanism : History, Status and Prospects", Review of Environmental Economics and Policy, Tome 1, n ${ }^{\circ}$, 134-15

MEUNIE A., 2004, «Quelles règles de partage de la charge pour la réduction des émissions de gaz à effet de serre? L'intégration des pays en développement dans la lutte contre le changement climatique et étude de cas de la Chine », Contribution pour le Colloque «La mondialisation contre le développement? » organisé par le C3ED, 10-11 juin 2004.

MEUNIE A. et QUENAULT B., 2007, Le financement du développement durable, Revue Tiers-Monde, $\mathrm{n}^{\circ} 192$, pp. 853-869.

NGUYEN N.T. et alii, 2010, Improving the Clean Development Mechanism post 2012: A developing country perspective, Working Paper CIRED, $\mathrm{N}^{\circ} 9$.

ORGANISATION INTERNATIONALE DE LA FRANCOHONIE, 2005, Onzième session de la Conférence des Parties de la Convention cadre des Nations-Unies sur les changements climatiques (CdP 11) première session de la Réunion des Parties du Protocole de Kyoto (RdP 1), Montréal, Canada-Québec, 28 nov. 9 déc.

REDDY B.S., ASSENZA G. B., 2009, The Great Climate Debate, Energy Policy, Vol.37, $\mathrm{n}^{\circ}$ 9, pp. 2997-3008

RHAMAN S.M. et alii, 2010, Will the Clean Development Mechanism Mobilize Anticipated Levels of Mitigation?, Policy Research Working Paper, $\mathrm{n}^{\circ}$ 5239, The World Bank.

SZYMANSKI T., 2002, The Clean Development Mechanism in China, The China Business Review, Novembre-Décembre, pp. 26-31.

TIMILSINA G. R., 2009, "Carbon Tax under the CDM: a unique approach for reducing greenhouse gas emissions in developing countries”, Climate Policy, 9, pp. 139-154

United Nations / Organisation des Nations Unies, 1998, Protocole de Kyoto, Convention Cadre des Nations-unies sur les Changements Climatiques (http://unfccc.int/resource/docs/convkp/kpfrench.pdf)

UNFCCC (Seres S., Haites E., Murphy K.) 2010, The Contribution of the CDM under Kyoto Protocol to Technology Transfer. 57p.

UNEP, 2000, Clean development mechanism - Introduction to the CDM, CSRis $\phi$ National Lab., UNEP Collaborating Centre on Energy and Environment.

UNEP 2011, CDM Pipeline 2011, UNEP Riso Center, Avril, Juilliet (http://cdmpipeline.org/)

VIEILLEFOSSE A., 2006, Que faire après Kyoto ? Les principaux enjeux, Revue d'Economie Financière, Mars, n83, 77-90.

VÖHRINGER F. et alii., 2010, Reinforcing the EU dialogue with developing countries on climate change mitigation, Fondazione ENI, Nota Di Lavoro, $\mathrm{n}^{\circ} 43$. 
WANKO H. et SMIDA S., 2001, Problématique du Mécanisme de Développement Propre et stratégie de développement durable pour les PVD, Colloque international Mondialisation, Energie, Environnement, Paris, 10-13 juin.

WINKELMAN A.G. et MOORE M.R., 2010, Explaining the differential distribution of Clean development Mechanism projects across host countries, Energy Policy, Vol.39, nº3, pp.1132-1143.

WORLD RESOURCE INSTITUTE \& IFC, 2009, Emerging Risks - Trends in Emerging Asia, April.

ZHANG Zhong Xiang 2009, "China in the transition to a low carbon economy", Fondazione ENI, Nota di Lavoro 76-2010. 